\title{
Teacher's Participation in Quality Assurance in Private and Public Secondary Schools in Uyo Local Education Committee, Akwa Ibom State, Nigeria: Administrators' Perspective
}

\author{
Ekaette Emenike Iroegbu*, Eno Etudor-Eyo \\ Department of Curriculum Studies, Educational Management and Planning, Faculty of Education University of \\ Uyo, Akwalbom State, Nigeria
}

*Corresponding Author: Ekaette Emenike Iroegbu, Department of Curriculum Studies, Educational Management and Planning, Faculty of Education University of Uyo, AkwaIbom State, Nigeria

\begin{abstract}
The study explored teacher's participation in quality assurance in private and public secondary schools in Uyo Local Education Committee, Akwa Ibom State. Four research questions and four null hypotheses were raised to guide the study. The ex-post facto survey design was used to carry out this study. The population of the study comprised 64 principals distributed into 64 private and public schools in Uyo Local Education Committee. Random sampling technique was used to select 28 principals from the 64 schools in the area. A researcher developed instrument titled "Administrators' Perspective of Teachers' Participation in Quality Assurance Questionnaire (APTPQAQ)" was used to gather the data. The reliability of the instrument was determined using Cronbach Alpha analysis. A coefficient value of 0.830 was obtained for the APTPQAQ. Mean and Standard Deviation was used to answer the research questions while independent t-test was used in analyzing the hypotheses at 0.05 level of significance. The findings revealed that private and public schools significantly differ in quality assurance based on teachers' participation in instructional delivery, classroom management, evaluation activities and communication skills. Based on the findings of this study, it is recommended among others that, administrators should ensure that teachers monitors students through a variety of appropriate evaluation techniques in both private and public schools in order to ensure that the areas where the students are not doing so well are re-visited.
\end{abstract}

Keywords: Teachers, participation, quality, assurance, private, public, schools, administrator

\section{INTRODUCTION}

Teachers are central to any consideration of schools, and a majority of educational policy discussions focus directly or indirectly on the role of teachers. There is a prima facie case for the concentration on teachers' participation because they are the largest single budgetary elements in schools. Teachers are those who are directly involved with the learners and they help to evaluate both the learning programme and the students. The teacher facilitates the acquisition of desirable knowledge, skills and inculcates societal acceptable attributes into the learners for present and future development (Madumere-Obike, Nwabueze \& Ukala, 2013). The roles of teachers have evolved from merely being teacher-centered, to one that is student-centered and the skills required for quality teaching are also changing. Parents, practitioners and policymakers agree that the key to improving private and public education in Nigeria is placing highly skilled and effective teachers in all classrooms. No educational system rises above the quality of its teachers.

Quality is usually associated with highly professional performance and there is a direct link in the field of education between teacher's quality and quality assurance. Quality is something good, ideal or high standard. Quality education provided by trained and supported teachers are said to be the right of every citizen and not the privilege of the few. Any statement about quality implies a certain relative measure against a common standard. In education, quality emphasizes teachers' competence, creativity, commitment, and how educational administrators organize school activities in order to realize the full potentials of all personnel in educational institutions. It is the appropriateness and relevance of resources available for the achievement of educational goals and priorities, hence quality in education whether primary, secondary or tertiary institutions require adequate input and outputs (Onyedinachi, 2011). 
Quality educational standards are the goals to which all learners, teachers, staff and those who lead and manage schools should aspire to achieve. The topic of quality assurance has become one of the central topics in the context of recent educational reforms, and the concept of quality has become one of the most fashionable concepts in contemporary educational technology. Quality assurance involves a systematic procedure of verifying that education is meeting the specified conditions requisite to the actualization of its goals (Archibong, 2013). Quality assurance in education is the efficient management, monitoring, evaluation and reviews of the resource inputs and transformation (teaching and learning) to produce a quality output (students) that meets set standards and expectations of the society (Ayeni \& Afolabi, 2012). It ensures that evaluation processes are carried out according to set standards that bring about improvement in outcomes for learners. Quality standards should not be seen as the ceilings for schools as quality assurance is about continuous improvement and schools should aim at going beyond and above each standard.

The primary concern of a school administrator (principal) is to direct the activities of everyone in the school with great emphasis on the teachers towards the achievement of the school goals, aims and objectives. Enyi in Ogbonnaya (2013) opined that administrative role can be regarded as the sum total of the various processes of planning, organizing, stimulating, coordinating, staffing, budgeting, communicating and evaluating, which aids administrators in the utilization of resources in the achievement of organizational goals. Administrators emphasize repeatedly the fundamental role that teachers play in the determination of quality assurance. The goal of educational administration in secondary school is to get the teachers greatly involved in every step of the way by developing an all inclusive quality education that is accessible and relevant both in public and private secondary schools.

Private secondary schools are post-primary education also known as non-governmental schools where individuals, groups of persons, organizations or mission bodies come together to run and manage the affairs of the school. The schools are vested with the right to select their students and they are funded in part or whole by charging their students tuition rather than relying on mandatory taxation through public funding. Private school tuition is dependent on some factors such as school location, willingness of parents to pay, quality of infrastructure and the school's financial endowment. They claim that the high tuition fee is used to pay higher salaries for the best teachers, provide enriched learning environment, low student-to-teacher ratio, small class sizes and services such as libraries, science laboratory and computers. Most parents are of the view that private schools are better managed with a relatively higher standard of education, well behaved students with less disciplinary problems, better facilities, better performance in external and foreign examinations, and higher quality output.

Public secondary schools are schools that ensures that the education and upbringing of pupils are organized and operated to be a deliberate model of the civil community and state in which it functions. The most popular choice for high school level education is the public school. They have come under heavy scrutinization resulting in academic standard reform. They get their financing from local, state and federal government funds and in most cases, must admit all students who live within the borders of their district. They are mandated for or offered to all children without charge, funded in whole or in part by taxation. Since the schools are controlled by the government, the curriculum is decided at a state or national level. All public schools follow the same curriculum.

To outline the major differences between private and public schools, table 1 has been created to show the various ways the two types of schools operate, their characteristics and structure.

Table1. Comparing Private and Public School

\begin{tabular}{|l|l|l|}
\hline S/N & \multicolumn{1}{|c|}{ PRIVATE SCHOOL } & \multicolumn{1}{|c|}{ PUBLIC SCHOOL } \\
\hline 1. & $\begin{array}{l}\text { It is autonomous and generates its own fund through } \\
\text { tuition, private grants and endowments }\end{array}$ & Funded by government and taxes \\
\hline 2. & $\begin{array}{l}\text { Access to school facilities due to small class size } \\
\text { and adequate provision }\end{array}$ & $\begin{array}{l}\text { Poor access to school facilities due to } \\
\text { overpopulation and poor funding }\end{array}$ \\
\hline 3. & Admission rate is controlled & Admission rate is not controlled \\
\hline 4. & High learners achievement & Low learners achievement \\
\hline 5. & $\begin{array}{l}\text { Limited quality facilities such as laboratories, } \\
\text { libraries, demonstration farms, playground, staff }\end{array}$ & $\begin{array}{l}\text { Adequately supplied facilities including } \\
\text { buildings, utilities like water supply, electricity }\end{array}$ \\
\hline
\end{tabular}


Teacher's Participation in Quality Assurance in Private and Public Secondary Schools in Uyo Local Education Committee, Akwa Ibom State, Nigeria: Administrators' Perspective

\begin{tabular}{|l|l|l|}
\hline & $\begin{array}{l}\text { quarters, halls, toilet facilities etc due to limited } \\
\text { space }\end{array}$ & $\begin{array}{l}\text { etc by government. Utilization of facilities } \\
\text { based on space is adequate. }\end{array}$ \\
\hline 6. & $\begin{array}{l}\text { Teachers-student ratio is small. Reasonably } \\
\text { controlled class size. }\end{array}$ & $\begin{array}{l}\text { Teachers-student ratio is wide. Large } \\
\text { overcrowded classrooms }\end{array}$ \\
\hline 7. & $\begin{array}{l}\text { They have less qualified teachers but pay more } \\
\text { individual attention to students }\end{array}$ & $\begin{array}{l}\text { More qualified teachers but pay less individual } \\
\text { attention to students }\end{array}$ \\
\hline 8. & $\begin{array}{l}\text { Low teacher's salary since it comes from tuition } \\
\text { fees }\end{array}$ & $\begin{array}{l}\text { Higher teacher's salary due to government } \\
\text { funding }\end{array}$ \\
\hline 9. & Teachers are not necessarily certified & $\begin{array}{l}\text { Teachers must be state certified or working } \\
\text { towards it }\end{array}$ \\
\hline 10. & They do not necessarily have regulations & They must follow regulations \\
\hline 11 & Have a common curriculum set at the national level & Curriculum is decided by the school board \\
\hline
\end{tabular}

Instructional delivery is an instructor's personal approach to teaching through the use of variety of strategies that support creative and critical thinking, problem solving and continuous growth and learning. Students must be presented with opportunities to develop their critical thinking skills by being trusted to be responsible for their own learning through well-planned instructional strategies (Yough, 2015). The class is a dynamic environment and it requires continuous modification of instruction to enhance learning for each student. Instructional delivery relates to teacher's preparedness and delivery of instructional materials with confidence, good knowledge of subject matter, presentation of learning content in a logical sequential order, and readiness to change to a more appropriate method when progress is inhibited. Teachers must be confident in public speaking, maintain appropriate eye contact, speak clearly and never use language or jargon that is out of the audience comfort zone. Feedback, positive reinforcement and regular scanning of the room should be applied to evaluate the students and to know whether or not they are engaged. According to Harvey and Green (2013), quality is based on how efficient the teachers are, how adequate the instructional materials and facilities needed for teaching and learning are. Different learning styles should be considered as one lesson plan may not work for everyone so as to accommodate kinesthetic, aural and visual learners. Abdul (2003) in his comparative study on the usage of modern teaching aids by teachers of public and private schools found out that both types of school teachers use teaching aids, but that teachers of private schools use more teaching aids and models comparatively.

The ability of a teacher to organize the classroom and manage the students' behaviour is an important prerequisite for classroom management. Class room management is crucial because it supports the proper execution of curriculum development, developing best teaching practices and putting them into action. According to Soheili, Alizadeh, Murphy, Bajestani and Ferguson (2015), classroom management can be explained as the actions and directions that teachers use to create a successful learning environment that have a positive impact on students achieving given learning requirement. Generally speaking, effective teachers tend to display strong classroom management skills, while the hallmark of the inexperienced or less effective teacher is a disorderly classroom filled with students who are not learning or paying attention. Classroom management techniques may appear simple, but the ability to seamlessly and successfully integrate them into instruction of students to ensure quality assurance typically requires a variety of highly developed techniques and a significant amount of skills and experience. Teachers who are capable of managing their classroom effectively will reassure better quality assurance. Halawah (2011) who examined factors that motivates students to learn from their perspectives found out that the teachers' personalities, teaching methodologies and positive classroom management are the main factors that motivate students to learn. Teachers must effectively manage their classrooms in order to foster a positive learning environment which will allow those positive connections between students and teachers to be made (Sayeski \& Brown, 2014).

Teachers' evaluation of students is an increasingly common component of quality assurance in schools. Beeby (2013) defined evaluation as the systematic collection and interpretation of evidence leading as part of the process of judgment of value with a view to action. Beane, Toepfer and Alessi in Nwite and Nwuche (2016) also defined evaluation as that process of defining how well we are doing, whatever it is we are trying to do. Evaluation gives educators and students data on student achievement even though some teachers do not carry this out effectively. When this is effectively carried out, it builds students' confidence in knowing their strengths and weaknesses and this confidence flows into their future activities. Teachers are able to assist students in their areas of 
weaknesses and move accelerated students beyond the current level of achievement. As stated by Okoro (2014, p.18), evaluation in education is concerned with the collection of data and the use of such data in assessing the effectiveness or quality of a programme or performance. Students' evaluation should be based on solving problems and real world application rather than grades emphasizing memorization.

Teachers' communication skill goes a long way in determining students' zeal to learn and be interactive in class. Communication according to the concise oxford dictionary means 'the science and practice of transmitting information' or 'the act of imparting, especially news'. These definitions clearly show the link between teaching and communication; teachers are constantly imparting new knowledge or transmitting information. Teachers can create highly engaging instruction by providing frequent opportunities for students to respond (Sayeski \& Brown, 2014). Teaching is generally considered as only fifty percent knowledge and fifty percent interpersonal and communication skills. Communication skills for teachers are thus as important as their in-depth knowledge of the particular subject which they teach (CSW, 2013). Overall improvement in a student is expected when communication skill of the teacher is given due importance. Thus, it is important that communication skill becomes an important ingredient of a teachers' professional competency.

\section{Statement of the Problem}

The quality of secondary education has come under severe criticism from stakeholders in the last few years, and it has become imperative for the deployment of some mechanisms to control and improve the educational quality. The teacher and teaching are central to issues of educational quality and it has been declared that no educational system can rise above its teachers. Observations have shown that there seems to be poor teachers' participation in ensuring quality assurance in public and private schools in Uyo Local Education Committee (LEC) and this can be seen in the areas of instructional delivery, classroom management, inadequate funding, evaluation, interpersonal relationship, inadequate facilities, and unqualified teachers among teachers. This has led to poor academic achievement, poor quality assurance, high rate of examination malpractice and high drop-out rate among others. To solve the problem of poor quality assurance in the area of teachers' participation both in private and public secondary schools, the root causes must first be identified and thereafter improved upon. Consequently, this paper examines teachers' participation in quality assurance in private and public secondary schools considering teachers' instructional delivery, classroom management, evaluation of students and communication skills.

\section{Purpose OF The STUdy}

The study was conducted with the following objectives

1. To ascertain the difference in teachers' participation in ensuring quality in instructional delivery between private and public secondary schools.

2. To examine quality assurance based on teachers' classroom management in private and public secondary schools

3. To determine the difference in quality assurance based on teachers' evaluation of students in private and public secondary schools.

4. To ascertain the difference in quality assurance based on teachers' communication skills in private and public secondary schools.

\section{RESEARCH QUESTIONS}

1. What is the difference in teachers' participation in ensuring quality in instructional delivery between private and public secondary schools?

2. In what way does quality assurance differ based on teachers' classroom management in private and public secondary schools?

3. How does quality assurance differ based on teachers' evaluation of students in private and public secondary schools?

4. What is the difference in quality assurance based on teachers' communication skills in private and public secondary schools? 


\section{NULL HYPOTHESES}

1. There is no significant difference in teachers' participation in ensuring quality in instructional delivery between private and public secondary schools

2. There is no significant difference in quality assurance based on teachers' classroom management in private and public secondary schools

3. There is no significant difference in quality assurance based on teachers' evaluation of students in private and public secondary schools

4. There is no significant difference in quality assurance based on teachers' communication skill in private and public secondary schools

\section{THEORETICAL UnDERPINNING}

The General System theory explains human behaviour as the intersection of the influences of multiple interrelated systems. The theory was propounded by an Austrian biologist Ludwig Von Bertalanffy in the 1960s. According to this theory, all systems are seen as a series of interrelated parts constituting an ordered whole and each subsystem influence other parts of the whole. That is, one part of the system must interact and depend on the other parts around it to function effectively. Olson and Defrain (2000) described system theory as a set of principles and concepts that can be applied to all types of systems, living and non-living. This theory is of great relevance to the educational system because interdependence of parts is one of its concepts. A school being a system has the concept of interaction and interdependence of parts or elements which are interconnected in such a way that if one part is changed, the other parts are automatically affected. The teacher represents a crucial component of the social system and for the set objectives to be achieved, all the other components must also function optimally and in harmony. Littlejohn and Foss (2008) observed that this interdependence is a pattern that organizes a system itself and the system is also self-regulated and controlled. This research is organized around the systems approach due to the relationship among inputs, process and outcomes, and the idea that positive, purposeful change will occur only when we can understand and improve the key components of quality processes. System inputs (should) influence process, and process subsequently influences outcomes, which in turn completes the cycle by affecting the inputs for the next iteration. This circular paradigm embraces the concept of continuous improvement and identifies areas of opportunity in the pursuit of quality assurance in schools. This shows that a social system is vast, interconnected and is made up of interactive relationships. This therefore contends that when special attention is given, the teachers will carry out their role very well and productively is likely to be high.

\section{Method}

The Ex-post facto design was used in carrying out this study. In this type of research, the researcher does not have direct control on the independent variables since their manifestation has already occurred. The study was an attempt to find out the difference in teachers' participation in instructional delivery, classroom management, evaluation of students and communication skills in quality assurance in private and public secondary schools in Uyo Local Education Committee, Akwa Ibom State. Data was collected from representative sample. Therefore the design was suitable for the study.

The area of the study is Uyo Local Education Committee. It is situated between the North and SouthEast corner of Akwa Ibom State. The area has fifty (50) private secondary schools and fourteen (14) public secondary schools. The targeted population for this study comprised all the principals in all the private and public secondary schools in the study area. According to 2015/2016 academic session, the population size was 50 principals from private secondary schools and 14 principals from public secondary schools making it a total of 64 principals. A random sample of 28 principals selected from the private and public secondary schools in the study area provided data for this study.

A researcher developed instrument titled "Administrators' Perspective of Teachers' Participation in Quality Assurance Questionnaire (APTPQAQ)" was used for data collection. The instrument had 20 items which were divided into four sub-sections. The first section with 5 items focused on eliciting information on teachers' instructional delivery, the second section with 5 items focused on teachers' classroom management, the third section with 5 items focused on teachers' evaluation of students, 
while the fourth section sought for information on teachers' communication skills. The items were structured on a 4-point scale of Strongly Agree (SA) $=4$ points, Agree (A) =3points, Disagree (D) $=2$ points and Strongly Disagree $(\mathrm{SD})=1$ point.The face and content validity of the instrument was established by three validates, one in Educational Technology, one in Educational Measurement and Evaluation, and one in Educational Management and Planning, all are lecturers in the faculty of Education, University of Uyo. The corrections and inputs of the validates were reflected before drafting and administration of the final instrument.

The reliability of the instrument was determined using Cronbach Alpha analysis. A reliability coefficient of .830 was obtained for the instrument. The research instrument was finally administered using two trained research assistants on a personal hand delivery and face to face contact with all the respondents. The data obtained were analyzed using mean, standard deviation and independent t-test statistics. All the null hypotheses were tested at 0.05 level of significance.

\section{Results}

In order to answer the research questions and test the null hypotheses, mean, standard deviation and independent t-test statistics were used and the results are presented in Tables 2- 5.

Table2. Independent t-test analysis of the difference in teachers' participation in ensuring quality in instructional delivery between private and public secondary schools

\begin{tabular}{|l|l|l|l|l|l|l|}
\hline Variable & Groups & $\mathbf{N}$ & \multicolumn{1}{|c|}{ Mean } & Std. Deviation & t-cal & t-crit \\
\hline \multirow{2}{*}{$\begin{array}{l}\text { Teachers participation in ensuring quality } \\
\text { in instructional delivery }\end{array}$} & Private & 14 & 17.71 & 1.33 & \multirow{3}{*}{4.28} & \multirow{2}{*}{2.06} \\
\cline { 2 - 6 } & Public & 14 & 13.79 & 3.17 & & \\
\hline
\end{tabular}

*significant at $P<.05 ; d f=26$

The result as shown in Table 1 reveals that the mean score of 17.71 obtained by the administrators from private schools is greater than that (13.79) obtained by their counterparts from public schools. This result implies that there is difference in quality assurance based on teachers' instructional delivery in private and public secondary schools with teachers from private schools using variety and highly developed instructional delivery methods than their counterparts in public schools.

The result in Table 1 also reveals that the calculated t-value of 4.28 is greater than the critical t-value of 2.06 at .05 level of significance with 26 degrees of freedom. With this result, the null hypothesis which earlier predicted no significant difference in instructional delivery in private and public secondary schools is rejected in favour of the alternative hypothesis since there is a significant difference.

Table3. Independent t-test analysis of difference in quality assurance based on teachers' classroom management in private and public secondary schools

\begin{tabular}{|l|l|l|c|c|c|c|c|}
\hline Variable & Groups & $\mathbf{N}$ & Mean & Std. Deviation & t-cal & t-crit \\
\hline $\begin{array}{l}\text { Quality assurance based on teachers } \\
\text { classroom management }\end{array}$ & Private & 14 & 16.43 & 2.90 & & \\
\cline { 3 - 7 } & & & & & 3.01 & 2.06 \\
\hline
\end{tabular}

*significant at $P<.05 ; d f=26$

The result as shown in Table 2 reveals that the mean score of 16.43 obtained by the administrators from private schools is greater than that (12.07) obtained by their counterparts in public schools. This result implies that there is difference in quality assurance based on teachers' classroom management in private and public secondary schools with teachers from private schools managing their classroom better than their counterparts in public schools.

The result in Table 2 also reveals that the calculated t-value of 3.01 is greater than the critical t-value of 2.06 at .05 level of significance with 26 degrees of freedom. With this result, the null hypothesis that says there is no significant difference in quality assurance based on teachers' classroom management in private and public secondary schools was rejected. This implies that there is significant difference in quality assurance based on teachers' classroom management in public and private secondary schools. 
Teacher's Participation in Quality Assurance in Private and Public Secondary Schools in Uyo Local Education Committee, Akwa Ibom State, Nigeria: Administrators' Perspective

Table4. Independent t-test analysis of difference in quality assurance based on teachers' evaluation of students in private and public secondary schools

\begin{tabular}{|l|l|l|c|c|c|c|c|}
\hline Variable & Groups & $\mathbf{N}$ & Mean & Std. Deviation & t-cal & t-crit \\
\hline $\begin{array}{l}\text { Quality assurance based on teachers } \\
\text { evaluation of students }\end{array}$ & Private & 14 & 16.57 & 2.93 & \multirow{2}{*}{3.30} & \multirow{2}{*}{2.06} \\
\cline { 2 - 7 } & Public & 14 & 11.50 & 4.94 & & \\
\hline
\end{tabular}

*significant at $P<.05 ; d f=26$

The result as shown in Table 3 reveals that the mean score of 16.57 obtained by the administrators from private schools is greater than that (11.50) obtained by their counterparts from public schools. This result implies that there is difference in quality assurance based on teachers' evaluation of students in private and public secondary schools with teachers from private schools participating more and carrying out students' evaluation than their counterparts in public schools.

The result in Table 3 also reveals that the calculated t-value of 3.30 is greater than the critical t-value of 2.06 at .05 level of significance with 26 degrees of freedom. With this result, the null hypothesis which predicted a no significant difference in quality assurance based on teachers' evaluation activities in private and public secondary schools was rejected. This implies that the observed difference was significant.

Table5. Independent t-test analysis of difference in quality assurance based on teachers' communication skills in private and public secondary schools

\begin{tabular}{|l|l|l|l|l|l|l|l|}
\hline \multicolumn{2}{|c|}{ Variable } & Groups & $\mathbf{N}$ & Mean & $\begin{array}{c}\text { Std. } \\
\text { Deviation }\end{array}$ & t-cal & t-crit \\
\hline $\begin{array}{l}\text { Quality assurance based on teachers } \\
\text { communication skills }\end{array}$ & Private & 14 & 18.71 & 1.27 & \multirow{2}{*}{3.78} & \multirow{2}{*}{2.06} \\
\cline { 3 - 6 } & & Public & 14 & 14.71 & 3.75 & \\
\hline
\end{tabular}

*significant at $P<.05 ; d f=26$

The result as shown in Table 4 reveals that the mean score of 18.71 obtained by the administrators from private schools is greater than that (14.71) obtained by their counterparts in public schools. This result implies that there is difference in quality assurance based on teachers' communication skills in private and public secondary schools with teachers from private schools communicating better than their counterparts in public schools.

The result in Table 4 also reveals that the calculated t-value of 3.78 is greater than the critical t-value of 2.06 at .05 level of significance with 26 degrees of freedom. With this result, the null hypothesis that says there is no significant difference in quality assurance based on teachers' communication skills in private and public secondary schools was rejected. This implies there is a significant difference in quality assurance based on teachers' communication skills in public and private secondary schools.

\section{DISCUSSION OF FINDINGS}

The study greatly demonstrated the essence of the type of school attended by individuals as this usually has a positive or negative implication based on quality assurance. The study outlined how teachers' participation can affect quality assurance in private and public secondary schools.

This study agrees with Omiko (2015) who posited that adequate skills is required by the teacher in selecting the appropriate instructional method, technique and teaching aid to fit the students' interest and understanding of the subject. This was also supported by Iqbal (2006) who submitted that teachers in private secondary schools use more than one teaching methodology, provide more instructional material for teaching, arrange more co-curricular activities, art and science exhibition as compared to public schools.

Krause, Duchesne and Bochner (2013) view a classroom as where teachers create enabling environment for students to know how to use the available time and resources, and also cooperate with their classmates to achieve quality learning. It was also observed that rules and daily routine stemming from teachers classroom management in private schools provided students with the 
enabling environment to work and interact with each other in teaching-learning process which eventually produces quality education as compared to public schools.

This study will help to transform educational activities and measure quality indicators towards educational outcomes thereby empowering administrators and teachers to improve quality assurance. This finding is in consonance with the study of Jimmy and Lock (1995) who summarized many studies comparing public and private schools and reported that private schools in Nigeria improved students' performance as measured by standardized test of verbal and mathematical skills than public schools.

Teachers can foster a good learning environment through the level of communication they have with the students. This finding agrees with the study of Yahaya (2010) who found that under the leadership of enthusiastic and communicative teachers, students were more likely to continue in independent study. This is also in line with the study of Halawah (2011) who posited that teacher's out-ofclassroom connection with their students makes them feel as if a teacher genuinely cares and is trying to build an informal relationship with them.

\section{CONCLUSION}

Private and public secondary schools need many changes and the teachers hold one of the key positions to bring about such changes. These changes can be effectively carried out through committed and efficient teachers' participation in quality assurance techniques. Based on the findings of this study, it will be appropriate to conclude that private and public schools significantly differ in quality assurance of teachers' participation in instructional delivery, classroom management, evaluation of students and communication skills. The private schools performed better than the public schools in all the indices mentioned. From a comparative perspective therefore, private schools are better than the public schools in Uyo Local Education Committee in Akwa Ibom State.

\section{RECOMMENDATIONS}

- Administrators should ensure that instructional delivery is more targeted and student-specific in private and public schools. Teachers should be encouraged to learn from best practices that make private secondary schools such an attractive option for both students and parents. Use of appropriate teaching technique and up-to-date information should be encouraged.

- Ministry of education should ensure that public schools organize their activities more effectively around academic achievement objectives in order to improve performance. A decongested programme should be undertaken through the construction of new schools and expansion of existing schools in areas where enrolment outweighs available facilities in order to make classroom management efficient.

- Educational managers should ensure that teachers monitors students through a variety of appropriate evaluation techniques in both private and public schools in order to ensure that the areas where the students are not doing so well are re-visited.

- The school principals should mobilize relevant stakeholders in the education sector to provide adequate learning resources and facilities, and build teachers' capacities on improvisation of instructional materials to enhance effective teaching and learning processes in secondary schools. Good communication skills should also be acquired by the teachers.

\section{REFERENCES}

[1] Abdul, I. (2003). Classroom instruction that works: Research-based strategies for increasing student achievement. Alexandria: Association for Supervision and Curriculum Development, 5 (3), 67-71.

[2] Archibong, I.A. (2013). Strengthening internal quality assurance for improved education delivery in Nigerian public universities. Research on Humanities and Social Sciences, 3 (1), 172-177.

[3] Ayeni, A.J. \&Afolabi, E.R. (2012). Teachers' instructional task performance and quality assurance of students learning outcomes in Nigerian secondary schools: International Journal of Research Studies in Educational Technological, 1(1), 33-42.

[4] Beeby, D.O. (2013). Guidance and counseling essentials. Calabar.O'Kenele Ventures. 
[5] Communication Skills World (CSW) (2013). Communication skills for teachers: An overview. Available at: www.communicationskillsworld.com/communicationskillsforteachers.html. Retrieved: May 28, 2017.

[6] Halawah, I. (2011). Factors influencing college students' motivation to learn from students' perspective.Education, 132 (2), 379-290.

[7] Iqbal, Z.N. (2006). A comparative study of English medium schools and Urdu medium schools of Sialkot city. Unpublished thesis of Master of Philosophy (Education). Department of Teacher Education: Faculty of Education: AllamaIqbal Open University.

[8] Jimmy, E. \& Lock, M.E. (1995). Public and private secondary education in developing countries: Comparative study. Washington D.C.: World Bank.

[9] Krause, K.L., Bochner, S. \& Duchesne. S. (2013). Educational psychology for learning and teaching. Australia: Thomson.

[10] Littlejohn, S.W. \& Foss, K.A. (2008). Theories of human communications. (9 ${ }^{\text {th }}$ edition).Belmont, CA: Wadsworth Cengage Learning.

[11] Madumere-Obike, C.U., Nwabueze, A.I. \& Ukala, C.C. (2013). Impact of good teaching on secondary school students for national transformation in South-Eastern States of Nigeria.AFTRA Teaching and Learning in Africa Proceedings.

[12] Nwite, O. \&Nwuche, R.A. (2016). Evaluation of students' personnel services in colleges of education in Nigeria. British Journal of Education, 4 (7), 82-98.

[13] Ogbonnaya, N.O., \& Oboegbulem, A.I., Onwura, C.U. \& Enyi, D. (2013). Fundamentals in educational administration and planning. Nsukka: Chuka Educational Publishers

[14] Okoro, D.O. (2014). Students riots and unrest in higher institutions of learning in developing countries; The Nigerian scene (1980-1999). In A.U. Akubue\& D. Enyi (Eds.).Crises and challenges in higher education in developing countries. Ibadan: Wisdom Publishers Ltd.

[15] Olson, D.H. \&Defrain, J. (2000).Marriage and the family. diversity and strengths. London: Mayfield Publishing Company.

[16] Omiko, A. (2015). Chemistry education for life and service to humanity: Panacea for wealth creation and national development in Nigeria. Journal of Education Foundation, Ebonyi State University, Abakaliki, Inprint.

[17] Onyedinachi, J.U. (2011). Adequacy and utilization of physical facilities for quality education in public senior secondary schools in Abia State. Unpublished doctoral dissertation.University of Port-Harcourt.

[18] Sayeski, K.L. \& Brown, M.R. (2014). Developing a classroom management plan using a tiered approach. Teaching Exceptional Children, 47(2), 119-127.

[19] Soheili, F., Alizadeh, H., Murphy, J.M., Bajestani, H.S.,\& Ferguson, E.D. (2015). The impact of Dreikurs classroom management techniques on students' perceptions of the classroom environment and on academic achievement. Journal of Individual Psychology, 71 (4), 440-461.

[20] Yahaya, N., Yahaya, A., Ramli, J., Hashim, S., \&Zakariya, Z. (2010). The effects of extrinsic motivational factors in learning among students in secondary schools in Negeri Sembilan. International Journal of Psychological Studies, 2 (1), 128-136.

[21] Yough, M., Heron, M., Richards, K.A., \& Ware, J.A. (2015). Working with what is brought: Promoting conceptual change in a course on learning. College Student Journal, 49 (3), 355-368

Citation: Ekaette Emenike Iroegbu, Eno Etudor-Eyo. "Teacher's Participation in Quality Assurance in Private and Public Secondary Schools in Uyo Local Education Committee, Akwa Ibom State, Nigeria: Administrators' Perspective." International Journal of Managerial Studies and Research (IJMSR), vol 6, no. 2, 2018, pp. 1-9. doi:http://dx.doi.org/10.20431/2349-0349.0602001.

Copyright: (C) 2018 Authors. This is an open-access article distributed under the terms of the Creative Commons Attribution License, which permits unrestricted use, distribution, and reproduction in any medium, provided the original author and source are credited. 